Social Work \& Education

() SWRE, 2018

\section{Lilia Ereimina,}

the assistant of the department of social life, social pedagogy and preschool education

Melitopol State Bogdan Khmelnitsky Pedagogical

University

Melitopol, Ukraine

yeromina_liliia@mdpu.org.ua

УДК: 37.033

DOI: $10.25128 / 2520-6230.18 .2 .9$

Article history:

Received: April 14, 2018

1st Revision: April 30, 2018 Accepted: May 24, 2018
Ereimina, L. (2018). Are 14-17-year-old boarding school pupils ready for family life?, Social Work and Education, Vol. 5, No. 2., pp. 88-99.

\section{ARE 14-17-YEAR-OLD BOARDING SCHOOL PUPILS READY FOR FAMILY LIFE?}

Abstract. The article is devoted to one of the topical problems of the present - the formation of readiness for family life of boarding school pupils. According to the State Statistics Service of Ukraine, for the period from 2013 to 2017, the number of orphans and children deprived of parental care fell by 19594 (from 90772 to 71178 ), but the number of adopted children during the same period, on the contrary, decreased by 769 people (from 3732 to 2963). As of 2017, the network of boarding schools in Ukraine has 663 institutions, in which there are more than 100 thousand pupils. According to the problem under the study, the author emphasizes on the fact that institutions of state maintenance are not able to provide the full experience of family relationships, whose models are assimilated directly in the family. The need for a family of pupils of boarding schools is much greater than the children who grow up in the family. Therefore, as it is emphasized in the article, it is very important to formulate in the consciousness of this category of children ideas about the culture of family relationships, to provide knowledge about family and marriage, responsible parenting, to actualize the motives for the implementation of appropriate actions by pupils for the elevation of the depth of the essence of family life. Indicating on the importance of the present processes of socialization in institutions of boarding type, the author of the article focuses on a number of aspects that contradict the ideas of the development of a harmonious person that would be prepared for the future family life. The presented materials reveal the factors of readiness for family life, characterizing their essence in accordance with the scientific achievements of modern scholars. On the basis of the results of the theoretical study of the topic of readiness of the pupils of institutions of boarding type for family life, the author identified the following factors of readiness for family life: the values of family life; motivation for family life; activities and acts within the framework of friendly relations of small groups; social controlled socialization purposeful influence by the teaching staff of the institution; personal desires and needs of older teenagers in interaction with family. The factors outlined in the publication are the factors of the readiness for family life of the pupils of intuitions of boarding type, the essence of which is that this process unfolds in the socio-cultural educational space and, taking into account the vitality of family relationships, gives grounds to assert that preparation for the family life of older teenagers requires a socio-educational escort.

Key words: the readiness for family; the pupils of intuitions of boarding type. 


\section{Introduction}

The topicality of the study of this topic is due to a number of innovative steps in the social policy of Ukraine. The present transformation in the field of social education requires the mobilization of efforts, in line with studies of youth readiness for family life. The processes of socialization in the institution of the boarding type contradict the idea of development of a harmonious person, which would be prepared for the future family life. The aim and objectives of the presentation of the material: to isolate and analyze the socio-pedagogical components of readiness for family life as factors of influence on older teenage students of institutions of boarding type.

\section{Methodology of the Research}

Leading experts in social work (O. Bezpalko, I. Trubavina, L. Kanishevsky and etc.) point out on high levels of vulnerable of pupils residential of intuitions of boarding type , caused by factors such as lack of skills necessary for independent living (budgeting, household, household problems, healthy lifestyle, etc.); existence of consumer position of pupils, so that they are not ready to take responsibility for their own actions, for their own life; the existence of so-called learned helplessness complex (negative experiences, shame on the status of pupils of boarding schools ); lack of knowledge about sex-role socialization and lack of social ties and so on.

In this regard, we believe that the socio-pedagogical provision of this process, namely, the formation of the readiness of the pupils of institutions of boarding type to family life, is to integrate the efforts of all pedagogical components: the administration and teaching staff of the institution, pupils and their parents or people who replace them.

\section{Results}

During the work on the topic of scientific research, we have determined that on the process of readiness of pupils of institutions of boarding type for family life is influenced by the set of factors that can ensure the effectiveness of the formation of this readiness. According to the interpretation of the academic dictionary, the term "factor" means the condition, the driving force, the cause of any process that determines its character or one of the main features (Shpekenenko, I. V., 2013, p. 101).

On the basis of the results of the theoretical study of the topic of the readiness of the pupils of institutions of boarding type to family life, we determine the following factors: the values of family life; motivation for family life; activities and acts within the framework of friendly relations of small groups; socially controlled socialization of purposeful influence by the teaching staff of the institution; personal desires and needs of older teenagers in interaction with family.

\section{Discussion}

Henceforth, we will present a detailed description of each factor. In accordance with the first factor - the notion of "value" we indicate that in the philosophy the theory of values presented V. Tugarinov and defined them as a measure of significance for a person of certain phenomena and objects and their properties, which appear as means of satisfactions of the needs and interests of man. 
Analyzing social factors of the formation of family values, A. Rogov points out on three main influential factors: the historical conditions in which the values of the family and family relationships were developed and formed; cultural-ideological aspects of life of society and family; economic factors that influence on the existence of a family (Rogova, A. M., 2006).

The importance of the influence of the family on the process of forming the values of family life is indicated in the work of T. Vecherok. Scientist distinguishes four groups of family traditions: in the sphere of nature use; in the sphere of life, work and rest; in the sphere of interpersonal relations and family traditions in the sphere of artistic culture and creativity. It is worth mentioning that it is precisely from the quantity and quality of the formed values of the individual that the formation of its spiritual world depends, because the values become an educational factor due to their transformation into internal motives. That is why the next factor in our readiness for family life is motivation for our family life.

In the scientific literature, "motive" is considered to be impellent reason for actions and deeds of a person. The initial motive for the activity is its needs. In any complex activity, a motive that plays a leading role is always highlighted. Investigating the development of personality, K. Jung emphasized on the fact that the young person has incomplete understanding of others as well as of himself, which is why there is a lack of awareness of the motives of other people and their own. Unidentified motives, according to K. Jung, have both personal and general nature, and the main thing is that the motives for marriage, the creation of a family are caused by parental influence. In this sense, for a young man, determining is the attitude towards the mother, and for the girl - to her father. According to L. Schneider, there are three motivations for marriage: the first motivation is the "fact of marriage", where the main driving force belongs to the intention to marry. At the same time, another person in such a process is only a means to fulfill the cherished desire - to marry or get married. In general, it's not important which partner is nearby. The second motivation is called "certain type of marriage". In these cases, there are more confident people, they are oriented on such a partner, which is able to fulfill their dreams and corresponds to the idea of a prestigious version of marriage relations. The third type of motivation belongs to the motive of "a certain person", when an individual or individual is perceived as a concrete real person, with all the weaknesses and disadvantages, that is, making a conscious choice with the installation of the acceptance of a certain person and the consequent personal responsibility for their feelings (Schneider, L. B., 2000).

A. A. Krasovsky noted the importance of social maturity of senior pupils in the ruling of a family, as an awareness of the social essence of marriage and of the basic social functions of the family. The teacher pointed out how well-formed the ideas and views on social maturity of the future spouses are as an important condition for marriage, how developed is a future husband and wife's responsibility before society for the family for the family they create (Krasovsky, A. S., 1990, p.18). In general, motives as a motivation for action, aimed at satisfying needs. There are two types of motives: conscious (interest, ideal, belief) and unconscious (suggestibility, attraction, setting). Unconscious motives only exist in poor-quality uncontrolled by consciousness leanings, which can be very strong. Studying the psychology of the family, S. Kovalev points out 5 types of motivation for marriage: love; spiritual intimacy; psychological 
responsibility; moral reasoning and material calculation. O. Stelmakh's scientific work on the status of a family in a modern society points out on the existence of such a motive for marital-family relations as a motive of a deficit that belongs to unconscious motives (an example of friends, a vicious self-esteem that stimulates excitement and the thirst for victory by any the feeling of inferiority with the installation of gratitude and sense of realization of the "last chance"; the pity, the benefit, the vengeance, the situation when the marriage union acts as a salvation from its problems, from itself, from fear of the future) (Stelmakh, O. M., 2010). Useful for our research are the views of V. Prit, Z. Okhrimenko, L. Koretskaya, who represent nine motives for marriage and family relations: human development, in revealing its best qualities, possibilities, abilities and creative potential exactly what will happen in family - a motive for creating a family that allows you to learn to give more than to receive, thereby multiplying love on Earth; the creation of own family in order to learn through love of husband / wife to love all, multiplying happiness and joy on Earth: the possibility of developing own freedom and multiplying it manifestations on the Earth; the opportunity to develop honesty in relationships, multiplying it on the Earth; family means the development of the best male and female qualities; the created family creates a true equality between a man and a woman; friendship between man and woman; the use of sexual energy to increase happiness and joy in themselves, in the family and on the Earth.

This is topical for our study, because the experience of life in the parent's family unknowingly affects the choice of partner, causing a number of difficulties. The unconscious connection complicates the choice and peculiar modifications. The indicated motives, both conscious and unconscious, encourage and direct the behavior of the pupils of the institution of the boarding type. Thus, the motives for marriage and the creation of a family essentially depend on the social status of the subject, his gender, age, the available values of life, and other factors

According to the results of empirical studies, we have found that the pupils of the institutions of boarding type cannot clearly answer the question "Why do you want to marry?", "Do you agree with the fact that love and friendship should exist between husband and wife?" etc. . The vast majority of respondents do not want to have a family at all, answering "I am good alone", "I do not want a family, because in the family only quarrels and disputes", etc. Also, among the answers of the responses were: "Yes, I want to have a family, like my aunt," or "I want a family, because I will have a rich man," and so on. This made it possible to determine that the pupils of the institution of boarding type are not motivated or motivated to family life, and motives such as the development of their own freedom in the family, the formation and increase of honesty and love, etc., are not considered at all by them. Thus, the motive as a factor of readiness for marriage and family relations is an important and inalienable component and needs to be studied in more detail in the process of forming the readiness of the pupils of the institution of boarding type for family life.

Among the factors for readiness for to family life that we distinguished, important is the activity that characterize at least by five acts that are basic for family life (deed-loyalty, deed-guardianship, deed-devotion, deed-sensitivity and deedsincerity). 
According to the interpretation of sociological and pedagogical dictionary for ed. V. Radul, activity is a way of being human in the world, the ability to make certain changes in reality. The main components of the activity are the subject with his needs; the purpose under which the object is transformed into the object to which the activity is directed; means for realization of the purpose and results of activity (Radul, V. V. , 2015, c.78).

According to I. Bech, an immediate and indirect act is an important indicator of moral development of the individual. An immediate act is an act that occurs face to face, it is genetically initial and, in the words of I. Bech, is an important part of the moral and spiritual experience. Accordingly, direct experience of pupils of institutions of boarding type should be enriched by the deeds we defined as basic for the formation of readiness for family life, which extends to small groups of people in the framework of friendly relations, their own family, thereby expanding the pupil's actual field.

The act of loyalty, as I. Bech points out, turns out to be a caring attitude. The scientist points to the following directions of the formation of the deed of loyalty, as an understanding of the need for objective and subjective necessity and the importance of observing social norms in their own behavior; forecasting of possible complications in interpersonal relationships in situations of deed-loyalty (evaluation by friends and peers, etc.); awareness of step-by-step deed-loyalty; emotional self-esteem of the result of the act of loyalty and the acquisition of a moral habit of deed-loyalty (Bech, I. D., 2015, p.752).

In I. Bech's opinion, the formation of a deed-guardianship, which by its very nature is a deed-carrying, is preceded by a long-term exercise in household blessings. The source of this act is empathy (Bech, I. D., 2015, p.779). I. Bech describes the deed of loyalty as being associated with the presence of higher feelings and experiences as a basis that determines the desire to do good to another without any interest (the effective sign is courtesy) (Bech, I. D., 2015, p. 752). Deed-sensitivity is determined by I. Bekh as a measure of the involvement of one person to the life of another (affairs, well-being, etc.). For the implementation of this act, it is important to have a single living space, for other possibilities - this is manifested in correspondence or telephone communications, etc. The formation of sensitivity, as prevented by the scientist, must begin with the awareness of the pupils of the need to participate in the lives of other people (families, friends) (Bech, I. D., 2015, p.756).

The deed-sincerity is most often manifested in friendship, greetings of traditional hugs or kisses. To act sincerely, in the opinion of I. Bech, these actions on the call of the soul and heart, defining the moral nature of man (Bech, I. D., 2015, p.769).

Defining deed-loyalty; deed-guardianship;deed-devotion; behavior-sensitivity and act-sincerity as the basis for the preparation of boarding-school children for family life, which ideally have to be among pupils, we agree with I. Bech's view that the teacher draws attention to these acts quite occasionally, and if discusses them with pupils, does it so superficially. According to the scientist, teachers and educators should specially create situations for correcting pupils not only in direct but also during mediated actions (Zvereva, I. D. , 2013, p.719).

So, the presence of the deeds that we identified as basic in the formation of readiness for family life has a close connection with socialization. 
Socialization, by V. Radul's definition, is the process of assimilating an individual to a certain system of knowledge, norms and values that are auxiliary in the functioning of a full-fledged member of society. Socialization contains sociallycontrolled processes of targeted influence and spontaneous processes (Radul, V. V., 2015, p.350). According to the encyclopedia for specialists in the social sphere, socialization is the process of man's entry into society together with his social connections and integration into various types of social communities, during which social values, knowledge, skills and abilities are formed or transformed (Zvereva, I. D. , 2013, p p.79).

Social experience of a person, social activity, social knowledge and social mobility make a significant impact on the effectiveness of socialization. Let's present their detailed analysis.

In the encyclopedia for specialists in the social sphere, edited by I. Zvereva, the term social experience is presented as one of the important components of socialization, represented by a set of practically acquired social knowledge, skills and abilities; a certain social change of a person, its formation and improvement in the course of interaction with the socio-cultural environment and other people. Social experience is acquired by a person in a culturally appropriate educational environment, covering the subject-space environment (everything that surrounds a person), social and behavioral environment (family members and families, friends, collectives, etc.), environment with events (orientation, social the importance and role of events that enable the identification of experience) and the information environment (information and its social significance, which is accessible to a person for knowledge and comprehension) (Zvereva, I. D. , 2013, p. 40).

Social activity, by definition of O. Bezpalko, is a description of the ways of life of an individual or group, which captures the conscious orientation of his activity and behavior to change the social environment, conditions, institutions in accordance with urgent needs, interests and goals. Another value of social activity, according to the scientist, is the ability of a person to initiate and implement socially meaningful transformations. In parallel with this definition, O. Bezpalko also notes social passivity, which is a special way of responding, namely, the alienation of a person from participation in solving socially important tasks (Zvereva, I. D. , 2013, p. 82).

Social knowledge is knowledge of a society that enables a person to successfully participate in social life. The most necessary social knowledge is represented in habits and practical skills, that is, knowledge of everyday life.

Social mobility, by definition of Sociological- pedagogical dictionary V. Radul, is a set of social movements of people in society, that is, change its status; directions, variety and distance of social movements of people in society (individually and in groups) (Radul, V. V., 2015, p.351). Social mobility P. Sorokin defines as any transition of an individual or a social object, that is, all that is created or modified by human activity, from one social position to another.

In accordance with social mobility, I. Shpectorenko points out two types of its existence: the horizontal (the transition of an individual or a social object from one social group to another that is at the same level) and the vertical (displacement of an individual or social object from one social reservoir to another). Depending on the direction of movement, scientists have identified two types of vertical mobility: 
ascending and descending, that is social lift and social descent. To indicate the result of the horizontal and vertical types of people's mobility in society, the concept of social elevator, which characterizes changes in both social status and place of human presence in society, is used. The notions of "social mobility" and "social lift" are not synonymous. Under social mobility, we mean the phenomenon, quality and resource of the individual, the result of the social activity of the individual, the criterion for assessing his social activity, activity as "up", and "down" (in the horizontal and vertical direction) (Shpekenenko, I. V., 2013).

Under the notion of "social elevator" N. Kovalisko understands the phenomenon of vertical mobility, an individual trajectory of social mobility of the individual, which occurs in interaction with social institutions, communities, groups. The social elevator, according to the scientist, is a conditional name of a set of factors, a system of objective conditions, principles, developed by social institutions and social communities, groups. The social lift affects the formation of the vertical social mobility of individuals, that is, it encourages competition and provides the mobile person with the direction "up" (selection of the best forms, methods and means). In this case, social institutions, organizations and communities can be considered as a "separate mechanism" of social lifts. Thus, the driving force of efficient social lifts is the interested parties (state, society). According to M. Bendukov, organization of effective activity in various directions in the restoration of the system of social lifts will in the long run allow to consider this system as a leading mechanism of social mobility, in particular, and the socialization of man in general. The content of the process of socialization, according to A. Kapskaya's views, is determined by the interest of society in the fact that its members actively held the role of husband and wife (gender socialization), active participation in economic life (professional socialization), the ability to create a strong family (family socialization), in law-obedience (political socialization) (Kapska, A. Y., 2013, p. 44).

In the encyclopedia for social sphere specialists three types of socialization are given: spontaneous, relatively directed and socially controlled. Spontaneous socialization occurs during the influence of various specially created circumstances of social life. Relatively directed socialization is aimed organizing certain conditions that affect the development and life path of the individual. Socially-controlled socialization of purposeful influence (upbringing) is a process of a specially-organized transfer of social experience that occurs in various state and non-governmental organizations (Zvereva, I. D. , 2013, p. 80).

Based on the what was said before, the following factor determines socially controlled socialization of the targeted influence from the teaching staff of the institution. Pupils enter the institution of boarding school for various reasons: some are from birth in public institutions, which determines their sensory, emotional, maternal, cognitive, psychological, and social deprivation. According to L. Kanishevskaya, life in institution of boarding type significantly reduces the range of sexual roles, blocking the initial self-identification with a person of the same sex, resulting in difficulties in gaining gender identity, which are manifested in the confusion of roles, which leads to misunderstanding of the content and tasks in performance of social roles of the father / mother in family life, etc. (Kanishevskaya, L. V., Sviridenko, S. O., Kuzmenko, L. V., 2015, p. 18). 
To determine socially controlled socialization of purposeful influence by the pedagogical institution of the boarding type, we have analyzed the content of the concepts of pedagogical and social influence. According to sociological-pedagogical dictionary V. Radula, pedagogical influence is the influence of the teacher on the consciousness, will, emotions of the pupils, on the organization of their lives and activities in the interests of forming the necessary qualities in them and ensuring the successful achievement of the goals (Radul, V. V., 2015, p.56). The content of the concept of social influence, V. Radul defines as a change in the knowledge, setting, behavior or emotions of a person. Social influence can be carried out in this perspective: coercion and punishment; legitimacy and punishment; information and expertise - belief in the competence of the source; referential - identification of the object of social influence with its subject. Thus, we believe that the socially controlled socialization of purposeful influence by the pedagogical staff of the institution of the residential type is the socio-pedagogical impact on the pupil in order to change his knowledge of the family and family values, behavior, focusing on any achievements. First of all, we believe that the true essence of socially controlling socialization of purposeful influence should be based on the following points: the pedagogical staff of the institution of the boarding type should reflect not their level, but social and pedagogical orientations; ability to put yourself in a pupil's place; in addition to the formation of knowledge, skills and abilities, it is important to teach pupils to observe and analyze their own deeds, actions and emotions, surrounding people (the analysis should be about positive phenomena) and nature.

The next factor of the readiness of the pupils of the institution of the boarding type is personal desires and needs of older teenagers in cooperation with the family. The term "need" in a pedagogical dictionary means the state of a living organism of a human person, a social group or a society as a whole, which means dependence on objective conditions of life and is the driving force of their activity. By the definition of $\mathrm{Z}$. Kyyantsa and $\mathrm{Zh}$. Petrochko, the needs of the child are the conditions that provide the basic support for the vital activity of the child's organism, the development of the child as a person that is very different from the needs of the adult (the child does not develop fully in the absence of love, emotional warmth of adults and appropriate environment). Scientists present the classification of the needs of the child, consisting of biological (physical development and healthy lifestyle), social (family well-being, love of parents, communication, cooperation, friendship, love, self-affirmation) and psychological needs (gaining new knowledge, aesthetic worldview, aesthetic creativity, emotional and value development, as well as self-knowledge, self-attitude and selfregulation) (Kanishevskaya, L. V., Sviridenko, S. O., Kuzmenko L. V., p. 40-41).

In the context of our study, we used the "hierarchy of needs" developed by A. Maslow. Let us note the earliest version of the scientist, presented at five levels of needs: physiological needs (breathing, nutrition, sexual need, and also - the need for safety); the need for reliability (health, material reliability, etc.); social needs (love, sense of belonging to a collective, family), whose satisfaction has a subjective character, because each person feels differently, for example, the need for communication, etc.; the need for respect and self-esteem (respect, social success, prestige, etc.); the need for personal development, the disclosure of their own potential; in self-realization; awareness of its purpose in the world (Maslow A., 2008). 
Exploring the psychology of the spiritual development of the personality, E. Pomytkin expanded the "hierarchy of needs" by A. Maslow ("I" is biological and "I" social), adding the "I" spiritual. According to the psychologist, the basis of any motivation of a person with high spiritual potential are the following levels: the motives of spiritual self-improvement (reproduction of a beautiful and perfect self); ministry (helping the needy, multiplying the good); wisdom (search and multiplication of truth); righteousness (observance of spiritual principles, reproduction of harmony in one's own life); holiness (acceptance and fulfillment of the spiritual mission, spiritual asceticism). According to E. Pomytkin, the result of human ascent to perfection is an invaluable biological, social and spiritual experience, which the spirit receives in its manifestation in the multidimensional nature of the individual. Instead, spiritual development, unlike personal, is due not only to the socialization and upbringing of man, but also to the awakening of its supreme spiritual nature, which can go beyond boundaries and contradict the nature of social (Pomitkin, E. O., 2005, p.36).

During the study of the readiness of the pupils of the institution of the boarding type to the family life according to the indicated factor, we identified the following personal desires and needs of older teenagers in interaction with the family: social, which determine the activities and behaviors of the pupils with age (needs for family ties, the desire to interact with brothers and sisters; the need for self-identification, selfrealization and self-presentation); psychological needs (intellectual and emotional development - getting knowledge about family and from family, satisfaction of aesthetic needs in interaction with family, etc.).

\section{Conclusions}

The factors of readiness for family life of pupils of the institution of the boarding type are outlined, the essence of which is that this process unfolds in the socio-cultural educational space and, taking into account the vitality of family relationships, gives grounds to assert that preparation for the family life of older teenagers requires social and educational support. The prospect of further research is seen in the implementation of a number of training programs aimed at forming the readiness of pupils of senior adolescence to family life.

\section{References}

Bech, I. D. (Chernivtsi: Bukrek, 2015). Selected scientific works in $2 \mathrm{t} .:$ T. 1

Gritshina, A. I., Kanishevskaya, L. V., Sviridenko, S. O., Kuzmenko, L. V, Bernatskaya, O. B., Karpushevskaya, L. R., Lyashchuk, O. S. (2015); Formation of family life values among pupils of residential institutions: monograph. Kharkiv: "Typography Madrid".

Zvereva, I. D. (2013). Encyclopedia for professionals in the social sphere (2nd edition) K., Simferopol

Krasovsky, A. S. (1990). Teaching Ethics and Psychology of Family Life at School: From Work Experience, Minsk: Nar. Asvet

Maslow, A. (2008). Motivation and personality (3-ed. [per. with english]) - St. Petersburg: Peter

Pomitkin, E. O. (2005). Psychology of spiritual development of personality: Monograph. $-\mathrm{K}$.: Our time 
Rogova, A. M. (2006). Analysis of social factors in the formation of family values among the younger generation by the example of St. Petersburg and the Leningrad region: author's abstract. diss to acquire a scholar. degree Candidate sociologist Science: special 12.00.03 / A. M. Rogov. Samara

Kuzminsky, A. I. (2002). Dictionary of reference pedagogical and psychological terms / [ed. - order. and others.] - Cherkassy: RVV BSD them. B. Khmelnitsky

Kapska, A. Y. (2009). Social pedagogy: Textbook. 4th view. corrections and add / Ed. prof. K.: Center for Educational Literature

Kiyannitsa, Z. P., Petrochko, Zh. V. (2017). Social work with vulnerable families and children: manual. In 2 hours,; Ch. Modern landmarks and key technologies- K .: ОБНОВА КОМАПАНІ

Radulov, V. V. (2015). Sociological-pedagogical dictionary. For zh.pedov. вид. 2nd Kharkiv: Machulin

Stelmakh, O. M. (2010). The status of a student's family in a modern society. Youth at the Beginning of the 21st Century: Key Values, Positions, Landmarksl: Materials IV International. scientific conf. young scientists, post-graduate students and students, March 30-31. Samara: Samara. state econ Unt.,- Part 2. - P. 148-151

Schneider, L. B. (2000). Psychology of family relations. Course of lectures. - M $\therefore$ April-Press, Publishing House EX-Press

Shpekenenko, I. V. (2013). Social lifts in the structure of the social mobility of the individual. Interdisciplinary research in science and education. - № 6. - P. 93-103. - [Electronic resource]. - Access mode: https://www.sziu.ru/media/uploads/ ук_13_6.pdf. with. 


\title{
ЧИ ПІДГОТОВЛЕНІ 14-17 РІЧНІ ВИХОВАНЦІВ ШКІЛ- ІНТЕРНАТІВ ДО СІМЕЙНОГО ЖИТТЯ?
}

\author{
Лілія Єрьоміна, асистент кафедри соціальної роботи, сочіальної \\ педагогіки та дошкільної освіти Мелітопольського державного \\ педагогічного університету імені Богдана Хмельницького \\ yeromina_liliia@mdpu.org.ua
}

\begin{abstract}
Анотація. Стаття присвячена одній 3 актуальних проблем сьогодення проблемі формування готовності до сімейного життя вихованців інтернатного закладу. За інформацією Державної служби статистики України за період 2013 2017 pp. кількість дітей сиріт та дітей, позбавлених батьківського піклування зменшилася на 19594 особи (з 90772 до 71178), але кількість всиновлених дітей за цей же період навпаки зменшилася на 769 осіб (з 3732 до 2963). Станом на 2017 р. мережа інтернатів в Україні нараховує 663 заклади, в яких перебуває понад 100 тисяч вихованців. Відповідно до досліджуваної проблеми, автор акцентує увагу на тому, що заклади державного утримання не мають можливості надати того повноцінного досвіду сімейних стосунків, моделі яких засвоюються безпосередньо у родині. Потреба у сім’ї у вихованців закладу інтернатного типу набагато більша, ніж у тих дітей, які зростають в родині. Через це, як підкреслено у статті, дуже важливим $є$ сформувати у свідомості даної категорії дітей уявлення щодо культури сімейних стосунків, надати знання щодо сім’ї та шлюбу, відповідального батьківства, актуалізувати мотиви щодо здійснення відповідних вчинків вихованцями для піднесення глибини сутності сімейного життя. Зазначаючи на важливості сьогоденних процесів соціалізації у закладі інтернатного типу, автор статті акцентує увагу на ряді аспектів, що суперечать ідеям розвитку гармонійної особистості, яка була б підготовлена до майбутнього сімейного життя. Представлені матеріали розкривають виокремленні дослідником чинники готовності до сімейного життя, характеризуючи їх сутність відповідно до наукових здобутків сучасних вчених. На основі результатів теоретичного дослідження теми готовності вихованців закладу інтернатного типу до сімейного життя, автором визначено такі чинники готовності до сімейного життя: цінності сімейного життя; мотивація до сімейного життя; діяльність та вчинок у межах дружніх стосунків малих груп; соціально контрольована соціалізація цілеспрямованого впливу з боку педагогічного колективу закладу; особисті бажання та потреби старших підлітків у взаємодії з родиною. Окреслені у публікації чинники готовності до сімейного життя вихованців закладу інтернатного типу, суть яких полягає в тому, що цей процес розгортається в соціокультурному виховному просторі i, враховуючи вітагенний досвід сімейних стосунків, дає підстави стверджувати, що підготовка до сімейного життя старших підлітків потребує соціально-виховного супроводу.
\end{abstract}

Ключові слова: готовність до сімейного життя, вихованці закладів інтернатного типу. 


\section{Література}

Бех, І. Д. (2015). Вибрані наукові праці. Виховання особистості. Вибрані наукові npaui: $y, 2$, т. 1.840 .

Грітчина, А. I. (2015). Формування цінностей сімейного життя у вихованців закладів інтернатного типу: монографія/Канішевська Л.В, Свириденко С.О, Кузьменко Л.В, Бернацька О.Б, Карпушевська Л.Р, Грітчина А.I, Лящук О.С;[за заг. ред. Канішевської Л. В]. Харьків: “Друкарня Мадрид.

Звєрєва, I. (2013). Енциклопедія для фахівців соціальної сфери.-2-ге видання/за заг. ред. проф. І.Д. Звєрєвої. Київ, Сімферополь: Універсум. 536.

Кияниця, 3. П., \& Петрочко, Ж. В. (2017). Соціальна робота із вразливими сім'ями та дітьми. Частина І. Сучасні орієнтири та ключові технології. 256 с.

Красовский, А. С. (1990). Преподавание этики и психологии семейной жизни в школе: Из опыта работы. Минск: Нар. асвета. 128.

Маслоу, А. Г. (2009). Мотивация и личность:[пер. с англ.]. Издательский дом" Питер". 352.

Помиткін, Е. О. (2005). Психологія духовного розвитку особистості: Монографія. К.: Наш час, 208, 1.

Рогова, А. М. (2010). Анализ сочиальныхх факторов формирования семейных ценностей среди молодого поколения на примере Санкт-Петербурга и Ленинградской области (Doctoral dissertation, автореф. дис.... к. соц. н). Самара. 20.

Словник-довідник педагогічних і психологічних термінів / [ред. - упоряд. А. І. Кузьмінський та ін.]. (2002).Черкаси : РВВ ЧДУ ім. Б. Хмельницького. 112.

Капська, А. Й. (2009). Соціальна педагогіка:[підручник]/За ред. проф. АЙ Капської.4-те вид. виправ. та доп-К.: Центр учбової літератури. 488.

Соціолого-педагогічний словник, за заг.пед.В. В. Радула. (2015). вид. 2-е. Харків: Мачулін, 444.

Стельмах, А. М. (2010). Статус студенческой семьи в современном обществе. Молодежь в начале XXI века: основные цеенности, позиции, ориентиры: материальл IV Междунар. науч. конф. молодых ученых, аспирантов и студентов, 30-31 марта 2010 г. Самара: Самар. гос. экон. ун-т. Ч.2. 148-151.

Шнейдер, Л. Б. (2003). Психология семейных отношений.158-159.

Шпекторенко И. В. Социальные лифты в структуре социальной моби Шпекторенко, И. В. (2013). Социальные лифты в структуре социальной мобильности индивида. Управленческое консультирование, (6 (54)). 93-103.

Bar-On, R. (2006). The Bar-On model of emotional-social intelligence (ESI). Psicothema, 18, 13-25.

Mayer, J. D. (2000). Models of emotional intelligence. J.D. Mayer, P. Salovey, D. Caruso; R. Sternberg. Handbook of Intelligence. Cambridge: Cambridge University Press, 396-420.

Mayer, J. D. (1993). The intelligence of emotional intelligence. Intelligence. N.Y., 433 $-442$.

Cooper, Robert K. (2000). EQ emotional intelligence in organization and management. Warszawa, Ayman Sawaf.

Salovey, P., \& Mayer, J.D. (1990). Emotional intelligence. Imagination, Cognition, and Personality, 9, 185-211.

Стаття надійшла в редакцію: 14 квітня, 2018 
